\title{
GENDER DIFFERENCE IN RURAL URBAN EDUCATION IN NEPAL
}

\author{
Kamal Prasad Panthhe \\ University of Leuven (KUL) and Hogeschool-Universiteit Brussel (HUB), \\ Belgium
}

Prof. Allan L.McCutcheon

University of Nebraska - Lincoln and Gallup Research Center, USA

\begin{abstract}
Using Nepal Living Standard Survey (NLSS 2003/04), this paper attempts to explore find the differences in education between men and women in urban and rural Nepal. Result shows that the urban populations have higher education compared to rural. Average years of schooling in urban Nepal were more than two times for both men and women; the gap in years of schooling between men and women is smaller in urban area compared to rural. In both rural and urban areas, the differences in education between men and women were smaller among the younger age group while it was higher for the older age groups. Probit model shows that the gender and location (urban/rural) area are significant determinants of schooling.
\end{abstract}

Keywords: Education, Nepal, Rural, Urban, Gender

\section{Introduction}

Nepal is an agrarian country and about $66 \%$ percent of the populations are dependent on agriculture for their livelihood, income and employment. Poverty in Nepal is a deeply entrenched and complex in nature with 31\% of Nepalese living below the poverty line (Economic Survey 2007). Several studies have found that both literacy and educational attainment are important determinants of individual and household welfare (Rahut 2007). Literacy and education affect the poverty level and the pace of economic development in a country.

Women are overworked, discriminated and have little time to participate in formal education; in addition to an onerous workload, their work is undervalued. Among poor household in Nepal, investment in education particularly in women's education is not perceived as good investment because in Nepal women go to their in-law's house after marriage. Rural poor household also need immediate income while return to 
education accrue after long period and only beyond certain level of education. Although women invest more time in subsistence and domestic work than men, they are viewed narrowly "as reproducers, not producers" and often have marginal control of how they spend their time. (UNIFEM 1995: 18).

Major contribution of this study is it attempts to explore educational difference by gender and location; the results of the study would help policy makers in formulating policies to reduce gender difference in education and also rural-urban difference in education. Paper would provide for formulating the policies for scaling up and out the adoption of new technology for increasing level education which in turn has significant affect in poverty reduction and development of the country.

\section{Educational Development in Nepal}

Nepal is small land locked country situated between two giants, China to the north and India to the south, east and west. According to the 2001 census (2001) the total population of the Nepal is 23.4 million and the population of Nepal was estimated at 29.51 million in 2008. Of the total population about $80 \%$ are living in rural areas and the rest are urban area. Nepal is a multi-religious, multi-ethnic, multi-lingual and multi-cultural society, which plays an important role in schooling of the children.

Education in Nepal is structured as school education and higher education. School education includes primary level of grades 1-5, lower secondary and secondary levels of grades 6-8 and 9-10 respectively. Preprimary level of education is also available in certain areas. Six years of age is the prescribed as the age for admission into grade one. A national level School Leaving Certificate (SLC) Examination is conducted at the end of grade 10. Grades 11 and 12 are considered as higher secondary level. Higher Secondary Education Board (HSEB) supervises higher secondary schools which are mostly under private management. Previously these grades were under the university system and were run as proficiency certificate level. Though some universities still offer these programs, the policy now is to integrate these grades into the school system.

Higher education consists of Bachelor, Masters and $\mathrm{PhD}$ levels. Depending upon the stream and subject, the Bachelor degree level may be of three to five years' duration. The duration of the Masters degree level is generally of two years. Some universities also offer M Phil and post-graduate diploma program.

Legally, there are two types of school in the country: community and institutional. Community schools receive regular government grant whereas institutional schools are funded by school's own or other non-governmental sources. Institutional schools are organized either as a non-profit trust or as a 
company. However, in practical terms, schools are mainly of two types: public (community) and private (institutional). A third type of school is the schools run by the local people enthusiastic towards having a school in their localities. They do not receive regular government grants and most of them do not have any other sustainable financial source. Supported and managed by the local people, they can be thus identified as the real community schools.

After the Rana Regime was over thrown in 1951, great effort made to establish the Nepal's Education System; the National Education Planning Commission was established in 1954, the National Education Committee in 1964 and the National Education Advisory Board in 1968. All these efforts were undertaken to upgrade the Nepal Education System. Education of Nepal has only recently started to develop. Nepal education has suffered a lot during the Rana Regime when education was suppressed; after that, education was given only to the aristocratic people of the society. New Education System of Nepal was established in 1971.

As a part of the five year plan, it was established to address individual needs, and the needs of society as a whole to mark national development. The main objective of the education system of Nepal was to develop midlevel managers and skilled man power. Universal Primary education with emphasis on the Nepali middle class was the main agenda. In 1980, there was an increase in private schools. Free school education policy and education for all became the slogan in the 1990's. Nepal's education system is based on the pattern of United States. It has received much help while forming the curriculum. From Grade 1- 5 is considered primary education while, 6-8 secondary and 9-10 upper secondary. The classes 11 and 12 are together considered higher secondary. A school leaving Certificate is granted to students after passing class ten. Education, Science, Humanities are the streams offered after for Higher Secondary and a certificate is issued after exam. Technical schools are also there.

\section{Literacy Situation of Nepal}

Although Nepal has been undertaking various literacy programs since 1956, large majority of Nepalese population are still illiterate. The number of illiterates has increased due to non-enrollment and high dropout rate of girls and disadvantaged children at primary schools. The growth of literacy does not even correspond to the growth of population in the country. The population growth rate is estimated at $2.25 \%$ per year while the literacy rate growth is only at the rate of $1 \%$ per year. 
Table 1 : Literacy trend in Nepal, 1980-2001

\begin{tabular}{lllll}
\hline & $\mathbf{1 9 8 0}$ & $\mathbf{1 9 9 0}$ & $\mathbf{1 9 9 8}$ & $\mathbf{2 0 0 1}$ \\
\hline 6+population & $12,180,000$ & $15,148,000$ & $18,047,000$ & $19,255,805$ \\
Literacy rate (\%) & $23 \%$ & $39 \%$ & $48 \%$ & $53.7 \%$ \\
Literate population & $2,801,400$ & $5,907,720$ & $8,662,560$ & $10,348,428$ \\
Illiterate population & $9,378,600$ & $9,240,280$ & $9,384,440$ & $8,787,413$ \\
\hline
\end{tabular}

Source: Literacy Watch Bulletin No. 5, NRC-NFE

According to 2001 census (see Table 1), the total literacy rate of the people aged 6 and above of Nepal was only 53.7\%. The literacy rate of women (42.48\%) was lower than the national average. The literacy rate of the 10-14 age group and 15-19 age group is comparatively high, being at $78.6 \%$ and $74.27 \%$ respectively. This is, however, far from satisfactory. The literacy rates of women in both the age groups are very low. The literacy rate of various age groups is given in Table 2 .

Table 2: Literacy rate among various age groups, 2001 (in percentage

\begin{tabular}{llll}
\hline Age Group & Total & \multicolumn{2}{l}{ Literacy rate } \\
\cline { 3 - 4 } & & Men & Women \\
\hline $8-9$ & 66.4 & 70.34 & 62.27 \\
$10-14$ & 78.6 & 83.7 & 73.2 \\
$15-19$ & 74.27 & 82.5 & 66.15 \\
$20-44$ & 51.74 & 67.66 & 37.82 \\
Nepal (6+) & 53.7 & 65.08 & 42.48 \\
\hline
\end{tabular}

Source: Census Report, CBS, 2001

Nepal is a male-dominant country and women have always less chance to study. The barriers to women participating in education are rooted in socio-cultural, economic and political realities that vary by community and even by family (Pennells, 1998). When families choose which children will or will not be educated, or which will have better educational opportunity, sons are preferred. Educating a son is investing in his ability to look after his ageing parents while educating a daughter is considered a noreturn investment. When she marries, she becomes another family's asset. Both the opportunity and cash costs of education lock girls out of schools. The majority of girls in Nepal are daughters of subsistence farmers living near or below the poverty line. Eldest daughters often provide care to most of the sibling. Farm and domestic work also pull girls out of school. Although tuition and books are free in public schools, other forms of student fees may be prohibitive.

\section{Hypotheses (Research Question)}

- In Urban areas the education differences between younger men and women are likely to be smaller than the differences in rural areas. 
- Literate parents are less likely to not send their children to school (In other words, literate parents are more likely to send their children to school).

- Rich household are less likely to not sent their children to school while poorer household are more likely to not send their children to school.

- Rural household are more likely to not send their children to school as compared to urban household.

- Male headed household are less likely not to send their children to school (in other words male headed household are more likely to send their children to school).

- Children in the mountain are less likely to go to school as compared to terai children (plain).

- Children whose parents are self in non-farm are more likely to go to school.

\section{Data and Survey Methodology}

The survey used a two pronged approach: a nationally representative cross-section survey to estimate trends and level of socioeconomic indicators and its different geographic regions; and a smaller panel survey to track exact changes experienced by those previously enumerated household during last eight years.

A household survey approach developed by the World Bank and applied in more than 50 developing countries is used here. Data were compiled for the current study regarding education, sex, age group and their educational activities in Rural and Urban areas. Different activities have been done to get the appropriate and representative data for the research such as, innovative data management techniques, including pre-coded questionnaire, field based data entry system, filed verification, extensive trainings and supervision of field workers. Inclusion of panel households concurrently with nationality representative sample households and collecting of information over a complete cycle of 12 months were partitioned into three pre-scheduled phases.

\section{Sample frame}

The 2001 population census of Nepal provided a basis for this survey's sample size. The size of each ward (as measured by number of households) was taken as a unit of sample frame. Some larger wards were divided into smaller units (sub-wards) of clearly defined territorial areas supported by reliable cartography while some of the smaller wards with fewer than 20 households were appended to neighboring wards in the same 
VDC. ${ }^{1}$ The resulting sampling frame consisted of 36,067 enumeration areas (wards or sub-wards) spread over 3 ecological zones ${ }^{2}$. This results in 5 development regions, 75 districts, 58 Municipalities and 3,913 Village Development Committees (VDCs) of the country. The sample frame was sorted by district, VDC, Wards and sub-ward and districts were numbered from geographical east to west.

\section{Stratification}

The total sample size (4,008 Households) was selected in two stages: 12 households in each of 334 primary sampling units. The sample of 334 PSUs was selected from six strata using probability proportional to size sampling with the number of households as a measure of size. The number are all multiples of 12 with the intention of implementing a two-stage selection strategy with that many households per PSU in the second stage. Within each PSU 12 households were selected by systematic sampling from the total number of households listed.

\section{Methodology}

According to National Living Standard Survey (NLSS, 2003/04), 38 $\%$ of population aged 6 years and older is literate in Nepal. According to 2001 census, the total literacy rate of the people aged 6 and above of Nepal was $53.7 \%$ and literacy rate of men and women are 65.08 and $42.48 \%$ respectively. This paper uses the Nepal Living Standard Survey Measurement (NLSSM), 2003/04 to analyze education patterns, education differential between rural and urban areas, between men and women and among the age groups in Nepal. The Nepal Living Standard Survey Measurement (NLSSM) 2003/04 has been carried by the Central Bureau of Statistics and it is comprehensive survey containing wide range of individuals and household variables including level of education between man and women in rural and urban areas. This paper does not use complicated econometric model rather simple descriptive statistics to analyze the education differentials.

\footnotetext{
${ }^{1}$ VDC in Nepal is lower administrative part of its local development ministry. There are 75 districts in Nepal. Each district has several VDCs. There are 3913 VDCs in Nepal And each VDC has nine villages.

${ }^{2}$ Three ecological zones are Mountains in the north (altitude 4877 to 8848 meters), Hills in the middle (altitude 610 to 4876 meters) and Tarai in the south. Mountains make up 35 percent of total land area of the country, while Hills and Tarai 42 percent and 23 percent respectively.
} 


\section{Data}

This paper uses the Nepal Living Standard Survey (NLSSM 2003/04) to explore the difference in education between male and female and urban and rural areas in Nepal. Two stage-stratified sampling has been used to select a nationally representative sample and population survey of 2004 has been used as the basis for sample selection. The Nepal Living Standard Survey 2003/04 enumerated 4,008 households from 334 primary sampling Units (PSU) in the cross sectional sample. The survey has a wide range of variables pertaining to the age, sex and their educational status in rural and urban areas. Data were collected through sample survey methods through personal interview of the households.

For this research, data has been compiled on the educational attainment of men and women in rural and urban areas. Information on literacy and educational status of the household members who are older than 5 years has been extracted and used for the analysis. Schooling/level of educational attainment, past enrollment/drop outs and current enrollment were captured to cover the proposed hypotheses. People were divided into three age groups namely the oldest group whose age were greater than 50 years, the Middle age group with an age between 30 to 50 years and the youngest group were below 30 years. The education attainment for different age group has been analyzed by gender and location (urban and rural areas). Educational status is categorized into three groups as never attended school, attended school in past and currently attending school.

Total respondents were categorized into three age groups on the basis of generation period youngest, middle and oldest age groups were below 30 years, 31 to 50 years and 50 years above age groups respectively.

\section{Empirical Analysis.}

Data were analyzed with the help of tabular and statistical methods of analysis to find out the results based on hypotheses. SPSS 16 type of software is used to analyze the data to get the appropriate results and probit regression model is run for hypothesis testing.

\section{Probit Model}

I also conducted a simple econometric analysis to find the determinants of the school dropout and level of schooling. (see table A.5 and A.5 in Appendix). This paper seeks to estimate the why children of school going age are not in school in Nepal by using probit model. The probit model directly yields an estimate of the probability of the occurrence of an event. This probability can be interpreted as the measure of the risk of nonschooling that have direct relevance to the keeping the children in school and in long run on poverty alleviation. Here we have used only the school going 
aged children for the analysis (i.e between the age of 7 and 15 years and the rest were dropped from the analysis.

$Y=1$, if children between the age of 7 and 15 are in school or 0 Otherwise The probability of children not being in school $[\operatorname{Pr}(Y=1)]$, is derived using the following equation:

$\operatorname{Pr}(Y=1)=\Phi\left[\sum_{k=1}^{K} \beta_{k} X_{k}\right] \rightarrow(2)$

Since the response is a binary outcome, the two events derived from disjoint sets are complementary and the probability associated with the alternative event (children being in school) is represented by:

$\operatorname{Pr}(Y=0)=1-\Phi\left[\sum_{k=1}^{K} \beta_{k} X_{k}\right] \rightarrow(3)$

Taking the partial derivative of the above equation with respect to the independent variable $X_{K}$, the marginal effect is obtained:

$\frac{\partial \operatorname{Pr} o b(Y=1)}{\partial X_{k}}=\Phi\left[\sum_{k=1}^{K} \beta_{k} X_{k}\right] * \beta_{k} \rightarrow(4)$

The probability of the $i$ th children being not in school, $P_{i}=P\left(Y_{i}=1\right)$, depends on a set of explanatory variables, $X_{i 1}, \ldots \ldots \ldots, X_{i k}$.

$Y_{i}=\alpha+\beta X_{i}+\varepsilon \rightarrow(5)$

$\varepsilon=$ Random error term

\section{Result and discussion}

Result from Descriptive Analysis

\begin{tabular}{|c|c|c|c|c|c|c|}
\hline \multirow[t]{2}{*}{ Educational Status } & \multicolumn{2}{|c|}{ Overall } & \multicolumn{2}{|c|}{ Men } & \multicolumn{2}{|c|}{ Women } \\
\hline & Mean & $\begin{array}{l}\text { Std. } \\
\text { Dev. }\end{array}$ & Mean & $\begin{array}{l}\text { Std. } \\
\text { Dev. }\end{array}$ & Mean & $\begin{array}{l}\text { Std. } \\
\text { Dev. }\end{array}$ \\
\hline $\begin{array}{c}\text { Years of schooling at National } \\
\text { Level }\end{array}$ & 3.20 & 4.19 & 3.99 & 4.44 & 2.47 & 3.80 \\
\hline Year of schooling in Urban Nepal & 5.39 & 5.06 & 6.35 & 5.13 & 4.45 & 4.81 \\
\hline Year of schooling in Rural Nepal & 2.37 & 3.46 & 3.05 & 3.74 & 1.75 & 3.06 \\
\hline $\begin{array}{l}\text { Years of Schooling for population } \\
<=30 \text { yrs old }\end{array}$ & 3.53 & 4.06 & 4.01 & 4.14 & 3.09 & 3.93 \\
\hline $\begin{array}{l}\text { Years of Schooling for population } \\
\text { between } 31 \text { yrs to } 50 \text { yrs }\end{array}$ & 3.43 & 4.77 & 5.24 & 5.13 & 1.85 & 3.77 \\
\hline $\begin{array}{l}\text { Years of Schooling for population } \\
\text { above } 51 \text { yrs }\end{array}$ & 1.36 & 3.45 & 2.32 & 4.28 & 0.39 & 1.89 \\
\hline
\end{tabular}


From the above table 3, overall mean of years of schooling is 3.20 years. Year of the schooling of the men and women are 3.99 and 2.47, respectively. It means men have spent more years in school than have women at the national level and it is much higher than last ten years for both men and women. Literacy rate is increasing day by day for men and women as well. Men and women literacy rates of the country stand at 63 and $39 \%$ respectively (NLSS, 2004). Here, we have found much difference between men and women.

Years of schooling of men and women in urban area are 6.35 and 4.45, respectively. It means men are more aware for education and they attended schools almost 2 years more than women. It also means than parents are likely to prefer to keep their son more in school than the female children. Years of schooling of men and women in rural areas are 3.05 and 1.75 respectively. Men spent many more years in school than the women in both urban and rural areas. There are dramatic differences between men and women in both areas. Years of schooling in urban area were more than twice that in rural areas (Victoria, 1998) for both men and women. There are major differences between rural and urban education. Yet most education reform efforts have been heavily urban oriented (Bloodsworth, 1993). Bloodsworth revealed that some of the conditions often associated with rural schools are: poverty, reform, generated problems stemming from the promotion of national standards and assessment, failure to consider basic inequities among schools, an unwillingness on the part of the rural students to seek individual recognition or to engage in individual competition, and the diversity of cultures within rural areas. It is suggested that in order to improve rural education the unique needs of rural schools and the characteristics of rural students must be understood and addressed. He argues that rural education must be based on academically demanding rural, not urban standards.

Years of the schooling for the under 30 years old population of men and women are 4.01 and 3.09 years, respectively. Between 31 to 50 years of the population of men and women are 5.24 and 1.85 years respectively. And 51 and above aged population of men and women are 2.32 and 0.39 years respectively. This indicates average years of Nepalese female have improved significantly and this suggests that the discrimination against female has declined. This is something that the country could celebrate on women's right.

People in urban areas have attended more years in school than rural areas. The years of schooling of the urban population are almost twice the rural population. Youngest people have attended more years in school than the older two age groups, this means that the parents are likely to be aware of the impact of education. In comparison between the three age groups, we have found the youngest people have small differences in both urban and 
rural areas. Men have attended more schools than women in both urban and rural areas.

Bowlby (2005) revealed the rural-urban gap in education, and argues that students in rural Canada are falling behind their urban counterparts. High school dropout rates are higher in rural areas. During the 2004/2005 school year, the rural dropout rate $(16.4 \%)$ was nearly twice as high as the urban dropout rate (9.2\%) in Canada.

Table 4: Years of schooling of different age groups in urban and rural areas

\begin{tabular}{|l|l|l|}
\hline Years of Schooling of the population & Urban & Rural \\
\hline Years of Schooling for population <=30 yrs old & 6.765 & 3.673 \\
\hline Years of Schooling for population between 31 yrs to 50 yrs & 6.394 & 2.006 \\
\hline Years of Schooling for population above 51 yrs & 2.763 & 0.591 \\
\hline
\end{tabular}

Above table 4 shows that years of schooling for youngest, middle and oldest people in urban areas were 6.765, 6.39 and 2.763 years respectively. Years of schooling for youngest, middle and oldest people in rural areas were 3.67, 2.006 and 0.591 years respectively. Here, we found that youngest people have higher education than other oldest people in both urban and rural areas. Differences among youngest, middle and oldest people in urban rural areas were 3.092, 4.388 and 2.172 respectively. It means education differences between urban and rural area is smallest between youngest people as compared to middle age group.

Rahut (2003) revealed in rural Nepal the marginal effect of the number of years of education is large because the average years of schooling of the head of household is quite small (1.8 years) as compared to urban Nepal (5.6 years). Hence, those people who have higher education tend to get better opportunities and have comparative advantages. There are large numbers of educated people in urban Nepal.

Table 5: Years of schooling of men and women in urban areas

\begin{tabular}{|l|l|l|}
\hline \multirow{2}{*}{ Years of schooling } & Urban \\
\cline { 2 - 3 } & Men & Women \\
\hline Years of Schooling for population <=30 yrs old & 7.216 & 6.319 \\
\hline Years of Schooling for population between 31 yrs to 50 yrs & 8.365 & 4.474 \\
\hline Years of Schooling for population above 51 yrs & 4.604 & 0.922 \\
\hline
\end{tabular}

Above table 5 shows years of schooling of men and women in urban areas for different age groups. Years of schooling of men in urban area for youngest, middle and oldest groups were 7.216, 8.365 and 4.604 years respectively. Years of schooling of women in urban area for youngest, middle and oldest groups were $6.319,4.474$ and 0.922 years respectively.

Differences of youngest, middle and oldest people were 0.897, 3.891 and 3.682 years respectively. Here, differences in education years between men and women is smallest among the younger people and is larger for two 
older age groups. This suggests that there is positive development in terms of female education and this is in line with Millennium Development Goal MDGs of providing equal opportunity to the female child.

Table 6: Years of schooling of men and women in rural areas

\begin{tabular}{|c|c|c|}
\hline \multirow{2}{*}{ Years of schooling } & \multicolumn{2}{|c|}{ Rural } \\
\cline { 2 - 3 } & Men & Women \\
\hline Years of Schooling for population $<=30$ yrs old & 4.430 & 3.008 \\
\hline Years of Schooling for population between 31 yrs to 50 yrs & 3.606 & 0.671 \\
\hline Years of Schooling for population above 51 yrs & 1.112 & 0.059 \\
\hline
\end{tabular}

Table 6 shows that years of schooling of men in rural areas for youngest , middle and oldest age groups were 4.430, 3.606 and 1.112 years respectively. Years of schooling of women in rural areas for youngest, middle and oldest age groups were 3.008, 0.671 and 0.059 years respectively. Youngest people have higher education than do the other two older groups. Both men and women have higher education in youngest generation.

In the rural areas the average years of education of oldest, middle and youngest aged male population are 1.112, 3.606 and 4.430 years. The average years of education of oldest, middle and youngest aged female population are $0.059,0.671$ and 3.008 years. This shows that the education level in the rural areas for both male and female are increasing. During the initially years of development the average years of education of male increased faster than that of female but in recent decades we find that the increase in the average years of education of female was higher. This indicates that the Nepalese female children got better education in recent years.

Urbanization shows a positive effect on men school attendance and a negative effect on women school attendance (Jayachandran, 2002). This paper also shows that the education of both men and women in urban areas is much higher than the rural areas, so this indicates that urbanization has positive influence on the schooling and education in Nepal. This supports our hypothesis that the urban children are more likely not to drop out form school.

The differences in years of schooling between men and women in urban areas for the youngest, middle and the oldest population group were 0.897 years, 3.891 years and 3.682 years respectively while the differences between men and women in rural area for the youngest, middle and oldest age groups were 1.422 years, 2.935 years and 1.053 years respectively. We found that the difference in years of schooling between men and women for the youngest group is least in both urban and rural area. We also found that the differences in years of schooling for both male and female population in 
both rural and urban areas are smaller for younger generation compared to the older generation, this suggest that the gender education disparity is declining and is an indication that the gender discrimination is being drastically reduced. However, the gender education disparity for the urban population is much lower than the rural population.

\section{Result from Econometric Analysis}

Based on the economic theory, the analysis uses the literacy dummy of the household, years of education and gender of the household head. It also uses the household size to capture the effects of the number of children in the house, and gender dummy of the children. In order to capture the effect of the location, we used the rural dummy, developmental regions dummy and ecological belt dummy. In order to capture the effect of the wealth of the household, we use the proxy variables like quality of the roof, types of toilets etc.

Like and other literature, this paper finds that the literate head are more likely to send their children to school as compared to the illiterate head. In developing countries like Nepal and India gender discrimination against female child is widely talked about, so we used the gender of the children to find that female child are less likely to go to school as compared to the male child. The wealth of the household as measure by the quality of housing (types of roof) and types of toilet also plays an important role in the schooling of the children. It is found that the richer households are more likely to send their children to school while the poorer household are more likely to not to send their children to school.

The rural dummy variable shows that the children in the rural areas are more likely not to go to school as compared to the children in urban area. From above analysis we found men have higher education than women in both areas. Demographic surveys (MoE Country Report, 1998) show that $40 \%$ of girls get married before they reach 15 years of age. Marriages of 10 or 12-year olds are not uncommon. With few exceptions, marriage ends their schooling. This adds to the cycle of maternal illiteracy that diminishes the chance of their daughters being schooled. Studies show that maternal illiteracy is a significant factor, far more than paternal illiteracy, in depriving daughters of schooling (UNICEF. 1996). Negative attitudes held by both sexes toward girls' education, especially among illiterate parents, have been well documented. Some groups fear that an educated girl will have a harder time finding a husband. Others believe that co-ed classes or walking more than short distances to school compromise their daughters' reputations and marriage prospects. In urban areas, teasing and risk of abuse or kidnapping are disincentives to girls schooling. The rampant absenteeism of teachers, often leaving classes unsupervised, increases parental anxiety. Schools are 
seldom girl-friendly. Many have no women teachers to act as role models. Few men teachers have had gender sensitization training to equip them to nurture the participation of girls or to validate girls' life experience within the classroom. The majority of primary schools have no toilets or running water. Class times often conflict with household or sibling care duties. Few schools have ECD programmes to free older sisters of their child care obligations. Hours of daily sibling care, domestic and farm work reduce girls' attendance and leave girls less time than boys to study, contributing to underachievement and dropout (Pennells ,1998). Women are overworked and have precious little time to participate in literacy programs (UNIFEM, 1995:18). In addition to an onerous workload, their work is undervalued. Education is not perceived as an efficient investment in increasing the cash, crop yields or other benefits they bring to the family. Although women invest more time in subsistence and domestic work than men, they are viewed narrowly "as reproducers, not producers" and often have marginal control of how they spend their time.

Marks (2009) revealed the modernization theory and changes overtime in the reproduction of socioeconomic inequalities in Australia that modernization theory argues that, as societies industrialize and further develop, the influence of social background and other ascribed characteristics on educational and subsequent socioeconomic outcomes declines, while achievement in the education system becomes more important. The effect of education on occupational attainment has increased more strongly among men than women. It was found that the effects of socioeconomic background on education specific government policies aimed at increasing equality of opportunity in education (Paterson \& Iannelli 2007). In contrast, declines over time in the overall (linear) relationship between socioeconomic background and educational attainment were found in most developed countries (Rijken, 1999). Gender inequalities in education have largely been reversed. In contrast to the late 1970s and early 1980s, a substantially higher percentage of young women than young men completed school and attend university (Fullarton et al. 2003, Marks et al. 2000b). Decline and reversal of gender differences in education have also occurred in many other countries (Blossfeld \& Shavit 1993, OECD 1996, 35, 320-321).

\section{Reason for not attending school}

According to the National Living Standard Survey (NLSS, 2003/04). (see tables in Appendix A1), There are several reasons for not attending school in Nepal. Reasons are absence of school, schools too far from the home, help at home, parents did not wanting children to attend, children not willing to attend and other reasons. Overall, 21.2 percent of the population never attended school. Among those who never attended school, 33 percent 
reported "parents did not want" as the primary reason. Other reason included "help at home" (20.3 percent), "too expensive" (19.3 percent), "not willing to attend" (13 percent) and "school far way" (3 percent).

Table A.2 shows that reason for not attending school of men for 'too expensive' is almost double in urban area than women in rural area. For women in rural areas, they found double the number for "parents did not want” is higher than men in urban area.

In comparison between men and women in urban and rural area, there are much differences have found among those who have never attended school. (table A 2, Appendix). The responses of "too expensive" (27 percent) is the most cited reason for men in urban area while "parents do not want” (38.4 percent) (table A3) is the dominant reason for women in rural areas, and it is more than double that for men in urban areas. The vast majority of parents did not want them to go to school for women in rural area, that would be the pattern of traditional society in rural area. We see that 12 percent of men have never attended school as compared to 30.1 percent of women.

Pennels (1998) revealed that the barriers to women participating in education are a maze of socio-cultural, economic and political realities that vary by community and even by family. When families choose which children will or will not be educated, or which will have better educational opportunity, sons are preferred. Educating a son is investing in his ability to look after his ageing parents while educating a daughter is considered a noreturn investment. When she marries, she becomes another family's asset. Both the opportunity and cash costs of education lock girls out of schools. The majority of girls in Nepal are daughters of subsistence farmers living near or below the poverty line. Eldest daughters often provide most of the sibling care. Farm and domestic work also pull girls out of school. Although tuition and books are free in public schools, other forms of student fees may be prohibitive.

\section{Reason for dropouts}

According to National Living Standard Survey, 2003/2004, table A 4 shows that distribution of the primary reasons for leaving school who attended school in the past. We found that 32 percent of those dropout cites "poor academic progress" while $27 \%$ report "help at home" as the primary reason for leaving school. Cost of the education is not the critical factors for dropping out of school as only 12 percent indicated "too expensive" to be the factor for dropping out of school. 


\section{Conclusion}

The conclusion drawn from the study is that the urban people have higher education than rural area. Years of the schooling in urban area was more than twice (Victoria, 1998) for both men and women and the differences in education in urban area is smallest than the rural area. The differences in education between men and women were smallest among the younger age group, and the differences for the two older age groups were large in both urban and rural areas. Nepal is men dominant country so women have always less chance to study than men due to some existing traditional society in rural area and urban people are more likely to adopt the modern patterns.

\section{References:}

Bloodsworth, G. (1993). Rural education and the urban reform movement, School of education, University of south Carolina. Aiken.

Bowlby, G. (2005). Provincial dropout rates trends and consequences. Education matters: insight on education, learning and trainings in Canada. Statistics Canada Catalogue number 81-004-XIE.

Blossfeld, H. P \& Shavit, Y. (1993). "Persisting Barriers: Changes in Educational Barriers in Thirteen Countries." Pp. 1-24 in Persistent Inequality. Changing Educational Attainment in Thirteen Countries,

Fullarton, S.,Walker, M., Ainley,J.\& Kylie, J. H.(2003). "Patterns of Participation in Year 12." No. 33. ACER.

Jayachandran, U. (2002). socio-economic determinants of school attendance in India, working paper No. 103 for Delhi School of Economics, India.

Allen, L. (2004). Modernization in Nepal, A study of the influence of westernization on defining deviant and illness behavior in a developing country, International Journal of Comparative sociology, Vol.45, 2004

Marks, G. (2009). Modernization theory and changes over-time in the reproduction of socioeconomic inequalities in Australia. Draft paper for Australian Council for Educational Research and University of Melbourne.

Marks, G. N., Fleming, N., Long, M, \& McMillan, J. (2000). "Patterns of Participation in Year 12 and Higher Education in Australia: Trends and Issues." LSAY Research Report, No. 17. Australian Council for Educational Research.

Ministry of Education/UNICEF. (1998). Girls Education in Nepal - Country Report Submitted to the International Conference on Girls' Education, May 6-8/98, in Washington, DC.

Nepal Living Standards Survey. (2003/04). statistical report vol.1. Central Bureau of Statistics, National Planning Commission Secretariat , Government of Nepal, December 2004. 
OECD. 1996. Education at a Glance: OECD Indicators. Organisation for Economic Co-Operation and Development. -. 2001. "OECD Earnings Data Base. ttp://www.oecd.org/dataoecd/61/28/1875507.xls."

Paterson, L. \& Lannelli, C.(2007). "Social class and educational attainment: A comparative study of England, Wales and Scotland .Sociology of Education 80 (4): 300-358.

Pennels, L. (1998). “Girl's and Women's education policies and implementation mechanism, case study: Nepal”, Bangkok: UNESCO principal regional office for Asia and the pacific.

Rahut, D. B. (2003) . "Determinants of poverty of Nepal” . Master thesis for University of Tsukuba, Japan .

Rahut D. B. 2006, Determinants of poverty in Nepal: a study of disadvantaged people. Globalisation and Human Rights. New Delhi, Serials Pub., 2006, viii, 172 p., figs., tables,. ISBN 81-8387-053-8.

Rijken, S. (1999).Educational Expansion and Status Attainment. A CrossNational and Overtime Comparison. Inter-University Center for Social Science Theory and Methodology.

Tammy A.Shel. (2007). Gender and inequality in education, Education for all by 2015: will we make it ?, education for all global monitoring report 2008, United Nations Education, Scientific and Cultural Organization (UNESCO).

UNIFEM. (1995). Mainstreaming Gender Consideration into N\&.ionnl Development Project Final Report: NEPI92lWO 1. Kathmandu.

Victoria, A.V. (1998). Women's education in India, International Programs Center, India.

\section{Appendix}

Table A.1: Reason for not attending school for all population 6-24 years old that has never attended school in percentage.

\begin{tabular}{|c|c|c|c|c|c|c|c|c|c|}
\hline & & \multicolumn{7}{|c|}{ Reason for not attending school } \\
\hline & $\begin{array}{c}\text { Who } \\
\text { have } \\
\text { never } \\
\text { attended } \\
\text { school }\end{array}$ & $\begin{array}{c}\text { Absence } \\
\text { of school }\end{array}$ & $\begin{array}{c}\text { Too } \\
\text { expensive }\end{array}$ & To far & $\begin{array}{c}\text { Help at } \\
\text { home }\end{array}$ & $\begin{array}{c}\text { Parents } \\
\text { did not } \\
\text { want }\end{array}$ & $\begin{array}{c}\text { Not } \\
\text { willing } \\
\text { to } \\
\text { attend }\end{array}$ & $\begin{array}{c}\text { Other } \\
\text { reason }\end{array}$ & Total \\
\hline Urban & 8.2 & 0.0 & 27.6 & 0.0 & 15.8 & 33.8 & 10.0 & 12.7 & 100 \\
\hline Rural & 23.5 & 1.5 & 18.8 & 2.9 & 20.5 & 32.8 & 13.1 & 10.6 & 100 \\
\hline Nepal & 21.2 & 1.4 & 19.3 & 2.7 & 20.3 & 32.8 & 12.9 & 10.7 & 100 \\
\hline
\end{tabular}

Source: NLSS 2003/2004 
Table A.2: Reason for not attending school for Men population 6-24 years old that has never attended school in percentage.

\begin{tabular}{|c|c|c|c|c|c|c|c|c|c|}
\hline & & \multicolumn{8}{|c|}{ Reason for not attending school } \\
\hline & $\begin{array}{c}\text { Who } \\
\text { have } \\
\text { never } \\
\text { attended } \\
\text { school }\end{array}$ & $\begin{array}{l}\text { Absence } \\
\text { of school }\end{array}$ & $\begin{array}{c}\text { Too } \\
\text { expensive }\end{array}$ & To far & $\begin{array}{l}\text { Help at } \\
\text { home }\end{array}$ & $\begin{array}{c}\text { Parents } \\
\text { did not } \\
\text { want }\end{array}$ & $\begin{array}{c}\text { Not } \\
\text { willing } \\
\text { to } \\
\text { attend }\end{array}$ & $\begin{array}{l}\text { Other } \\
\text { reason }\end{array}$ & Total \\
\hline Urban & 4.3 & 0.0 & 45.4 & 0.0 & 11.7 & 6.3 & 17.4 & 19.2 & 100 \\
\hline Rural & 13.2 & 1.9 & 25.5 & 3.7 & 15.2 & 18.5 & 19.4 & 15.7 & 100 \\
\hline Nepal & 11.9 & 1.8 & 26.6 & 3.5 & 15.1 & 17.8 & 19.4 & 15.9 & 100 \\
\hline
\end{tabular}

Source: NLSS 2003/2004

Table A.3: Reason for not attending school for Women population 6-24 years old that has never attended school in percentage.

\begin{tabular}{|c|c|c|c|c|c|c|c|c|c|}
\hline & \multicolumn{9}{|c|}{ Reason for not attending school } \\
\hline & $\begin{array}{c}\text { Who } \\
\text { have } \\
\text { never } \\
\text { attended } \\
\text { school }\end{array}$ & $\begin{array}{c}\text { Absence } \\
\text { of school }\end{array}$ & $\begin{array}{c}\text { Too } \\
\text { expensive }\end{array}$ & To far & $\begin{array}{c}\text { Help at } \\
\text { home }\end{array}$ & $\begin{array}{c}\text { Parents } \\
\text { did not } \\
\text { want }\end{array}$ & $\begin{array}{c}\text { Not } \\
\text { willing } \\
\text { to } \\
\text { attend }\end{array}$ & $\begin{array}{c}\text { Other } \\
\text { reason }\end{array}$ & Total \\
\hline Urban & 12.4 & 0.0 & 21.2 & 0.0 & 17.3 & 43.8 & 7.3 & 10.4 & 100 \\
\hline Rural & 32.9 & 1.3 & 16.3 & 2.6 & 22.5 & 38.1 & 10.7 & 8.6 & 100 \\
\hline Nepal & 30.1 & 1.2 & 16.5 & 2.4 & 22.2 & 38.4 & 10.5 & 8.7 & 100 \\
\hline
\end{tabular}

Source: NLSS 2003/2004

Table A.4: Reason for dropouts.

\begin{tabular}{|c|c|c|c|c|c|c|c|c|}
\hline & $\begin{array}{c}\text { Help at } \\
\text { home }\end{array}$ & $\begin{array}{c}\text { Too } \\
\text { expensive }\end{array}$ & $\begin{array}{c}\text { Poor } \\
\text { academic } \\
\text { progress }\end{array}$ & $\begin{array}{c}\text { Parents } \\
\text { did not } \\
\text { want }\end{array}$ & $\begin{array}{c}\text { Completed } \\
\text { desired level }\end{array}$ & $\begin{array}{c}\text { Moved } \\
\text { away }\end{array}$ & $\begin{array}{c}\text { Other } \\
\text { reason }\end{array}$ & Total \\
\hline Urban & 23.1 & 15.7 & 33.4 & 6.1 & 4.6 & 3.2 & 13.9 & 100 \\
\hline Rural & 27.5 & 10.7 & 31.3 & 8.9 & 3.7 & 4.7 & 13.3 & 100 \\
\hline Nepal & 26.8 & 11.5 & 31.6 & 8.5 & 3.8 & 4.5 & 13.4 & 100 \\
\hline
\end{tabular}

Source: NLSS 2003/2004

Table A.5:Statistics of variables used in the analysis.

\begin{tabular}{|c|c|c|c|c|c|c|}
\hline Statistics & $\begin{array}{c}\text { Education } \\
\text { Level }\end{array}$ & Age & $\begin{array}{c}\text { Household } \\
\text { Size }\end{array}$ & $\begin{array}{c}\text { Distance to } \\
\text { Primary } \\
\text { School (min) }\end{array}$ & $\begin{array}{c}\text { Dry } \\
\text { Land (in } \\
\text { acres) }\end{array}$ & $\begin{array}{c}\text { We } \\
\text { Land } \\
\text { (in } \\
\text { acres) }\end{array}$ \\
\hline Mean & 5.82 & 44.48 & 6.65 & 17.47 & 0.27 & 0.40 \\
\hline median & 9.90 & 42.00 & 6.00 & 10.00 & 0.03 & 0.10 \\
\hline $\begin{array}{c}\text { Standard } \\
\text { Deviation }\end{array}$ & 4.58 & 11.54 & 2.97 & 26.67 & 0.53 & 0.82 \\
\hline $\begin{array}{c}\text { Standard } \\
\text { Error (mean) }\end{array}$ & 0.68 & 0.17 & 0.04 & 0.39 & 0.01 & 0.01 \\
\hline $\begin{array}{c}\text { Coefficient of } \\
\text { Variation (cv) }\end{array}$ & 0.79 & 0.26 & 0.45 & 1.53 & 1.98 & 2.05 \\
\hline
\end{tabular}


Table A.6:Probit regression: determination of no schooling for children aged 7 to 15 years

\begin{tabular}{|c|c|}
\hline Variables & Coefficients \\
\hline \multirow[t]{2}{*}{ Education Level } & 0.002 \\
\hline & $(0.001)$ \\
\hline \multirow[t]{2}{*}{ If the head is literate ${ }^{a b}$} & $-0.530^{* * *}$ \\
\hline & $(0.137)$ \\
\hline \multirow[t]{2}{*}{ Age } & -0.005 \\
\hline & $(0.003)$ \\
\hline \multirow[t]{2}{*}{ Rural $^{\text {ac }}$} & $0.340 * * *$ \\
\hline & $(0.130)$ \\
\hline \multirow[t]{2}{*}{ Male Headed ${ }^{\text {ad }}$} & $0.442 * * *$ \\
\hline & $(0.081)$ \\
\hline \multirow[t]{2}{*}{ Male Child ${ }^{\text {ae }}$} & $-0.656^{* * *}$ \\
\hline & $(0.071)$ \\
\hline \multirow{2}{*}{ Household Size } & 0.019 \\
\hline & $(0.013)$ \\
\hline \multirow[t]{2}{*}{ Distance to Primary School } & 0.002 \\
\hline & $(0.002)$ \\
\hline \multirow[t]{2}{*}{ Eastern Developmental Region ${ }^{\text {af }}$} & 0.009 \\
\hline & $(0.152)$ \\
\hline \multirow[t]{2}{*}{ Central Developmental Region ${ }^{\text {af }}$} & 0.213 \\
\hline & $(0.149)$ \\
\hline \multirow[t]{2}{*}{ Western Developmental Region ${ }^{\text {af }}$} & $-0.458 * *$ \\
\hline & $(0.196)$ \\
\hline \multirow[t]{2}{*}{ Mid-West Developmental Region ${ }^{\text {af }}$} & -0.038 \\
\hline & $(0.159)$ \\
\hline \multirow[t]{2}{*}{ Mountain Ecological Belt ${ }^{\text {ag }}$} & $-0.333^{* * *}$ \\
\hline & $(0.121)$ \\
\hline \multirow[t]{2}{*}{ Hill Ecological Belt ${ }^{\text {ag }}$} & -0.125 \\
\hline & $(0.155)$ \\
\hline \multirow{2}{*}{ Mud Roof House ${ }^{\text {ah }}$} & -0.059 \\
\hline & $(0.265)$ \\
\hline \multirow[t]{2}{*}{ Wooden Roof House ${ }^{\text {ah }}$} & 0.509 \\
\hline & $(0.355)$ \\
\hline \multirow[t]{2}{*}{ Zinc Sheet Roof House ${ }^{\text {ah }}$} & $-0.907 * * *$ \\
\hline & $(0.121)$ \\
\hline \multirow[t]{2}{*}{ Tile Roof House ${ }^{\text {ah }}$} & $-0.487 * * *$ \\
\hline & $(0.105)$ \\
\hline \multirow[t]{2}{*}{ Cement Roof House ${ }^{\text {ah }}$} & $-0.459 * * *$ \\
\hline & $(0.154)$ \\
\hline \multirow[t]{2}{*}{ Other Roof House ${ }^{\text {ah }}$} & $-0.710^{*}$ \\
\hline & $(0.439)$ \\
\hline \multirow[t]{2}{*}{ House with Flush Toilet ${ }^{\text {ai }}$} & $-0.385^{*}$ \\
\hline & $(0.210)$ \\
\hline \multirow[t]{2}{*}{ House with Community Toilet ${ }^{\text {ai }}$} & -0.024 \\
\hline & $(0.432)$ \\
\hline \multirow{2}{*}{ House without toilet $^{\text {ai }}$} & $0.402 * *$ \\
\hline & $(0.160)$ \\
\hline
\end{tabular}


Dry Land (Acres)

Wet Land (In Acres)

$-0.147 * *$

If head is wage employed in non-farm ${ }^{\text {aj }}$

If head is self employed in farm ${ }^{\mathrm{aj}}$

$-0.138$

If head is self employed in non-farm ${ }^{\text {aj }}$

Constant

$\begin{array}{cc}\text { Number of observation } & 4568 \\ \text { Wald chi2(28) } & 472.75 \\ \text { Prob > chi2 } & 0.000 \\ \text { Log pseudo-likelihood } & -1437.07 \\ \text { Pseudo R2 } & 0.2576\end{array}$

Robust standard errors in parentheses. Standard Err. Adjusted for 72 clusters in district code ${ }^{a}$ dummy variables; ${ }^{b}$ excluded category: literate; ${ }^{c}$ excluded category: urban; ${ }^{d}$ excluded category: female headed; ${ }^{e}$ excluded category: female child; ${ }^{f}$ excluded category: far-west developmental zone; ${ }^{g}$ excluded category: terai (plain) ecological belt; ${ }^{h}$ excluded category: thatch roof house; ${ }^{i}$ excluded category: house with pit toilet $;{ }^{j}$ excluded category: household head with wage employment in farm; ${ }^{* * *},{ }^{* *}$, and ${ }^{*}$ indicate significance at the $1 \%, 5 \%$, and $10 \%$ level. 